\title{
DRAFT
}

\section{Geothermal Energy Program}

\author{
Multiyear Plan \\ FY 1992-1997
}

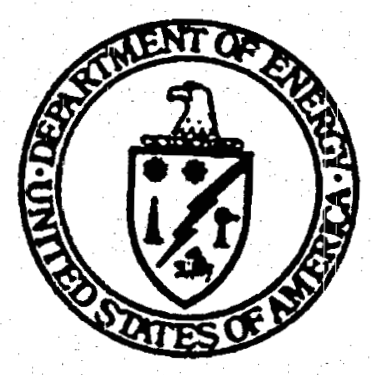

\section{Geothermal Division U.S. Department of Energy}

\author{
June 27, 1991
}

This material is for internal planning and management purposes. Budget figures, similarly, are for purposes of planning and for making assumptions explicit. They have not been approved as U.S. Government budget figures or projections. 


\section{DISCLAIMER}

This report was prepared as an account of work sponsored by an agency of the United States Government. Neither the United States Government nor any agency Thereof, nor any of their employees, makes any warranty, express or implied, or assumes any legal liability or responsibility for the accuracy, completeness, or usefulness of any information, apparatus, product, or process disclosed, or represents that its use would not infringe privately owned rights. Reference herein to any specific commercial product, process, or service by trade name, trademark, manufacturer, or otherwise does not necessarily constitute or imply its endorsement, recommendation, or favoring by the United States Government or any agency thereof. The views and opinions of authors expressed herein do not necessarily state or reflect those of the United States Government or any agency thereof. 


\section{DISCLAIMER}

Portions of this document may be illegible in electronic image products. Images are produced from the best available original document. 


\title{
DRAFT
}

\section{Geothermal Energy Program}

\author{
Multiyear Plan \\ FY 1992-1997
}

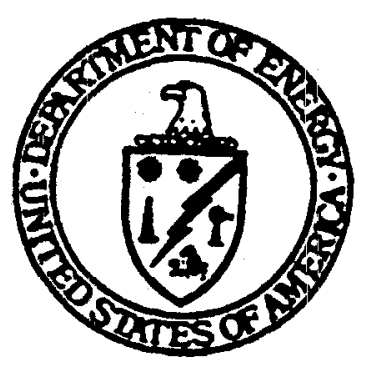

\author{
Geothermal Division \\ U.S. Department of Energy
}

June 27, 1991

This material is for internal planning and management purposes. Budget figures, similarly, are for purposes of planning and for making assumptions explicit. They have not been approved as U.S. Government budget figures or projections. 


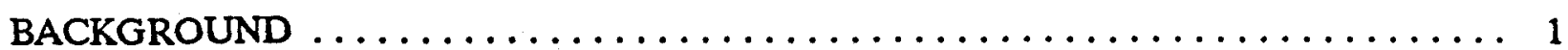

Status of Geothermal Development $\ldots \ldots \ldots \ldots \ldots \ldots \ldots \ldots \ldots \ldots \ldots$

The Investment $\ldots \ldots \ldots \ldots \ldots \ldots \ldots \ldots \ldots \ldots \ldots \ldots \ldots \ldots \ldots \ldots$

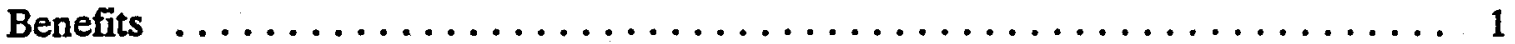

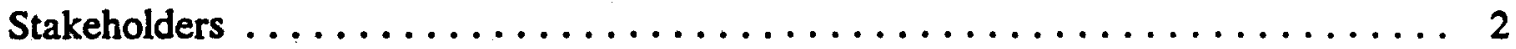

Government's Role to Date . . . . . . . . . . . . . . . . . . . 2

THE VISION $\ldots \ldots \ldots \ldots \ldots \ldots \ldots \ldots \ldots \ldots \ldots \ldots \ldots \ldots \ldots \ldots \ldots$

Technology Development Needed for Power Generation/Energy Supply . . . . . . . . 5

Potential Needs in U.S. Geothermal Infrastructure . . . . . . . . . . . . . . . 6

Obstacles to Geothermal Development .................... 6

Options for Removal or Alleviation of Obstacles $\ldots \ldots \ldots \ldots \ldots \ldots \ldots \ldots 7$

Key Participants Needed for Success . . . . . . . . . . . . . . . . 8

THE OBJECTIVES $\ldots \ldots \ldots \ldots \ldots \ldots \ldots \ldots \ldots \ldots \ldots \ldots \ldots \ldots \ldots \ldots$

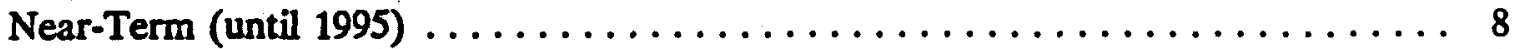

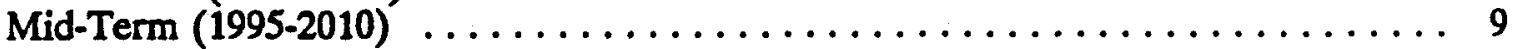

Long-Term (post 2010) $\ldots \ldots \ldots \ldots \ldots \ldots \ldots \ldots \ldots \ldots \ldots \ldots \ldots \ldots$

THE STRATEGY $\ldots \ldots \ldots \ldots \ldots \ldots \ldots \ldots \ldots \ldots \ldots \ldots \ldots \ldots \ldots$

Primary Research Activities by Year and Expected Incremental Products . . . . . 10

Monitoring of Infrastructure Conditions $\ldots \ldots \ldots \ldots \ldots \ldots \ldots \ldots \ldots \ldots \ldots \ldots$

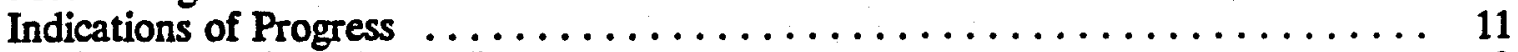

Ancillary or Spin-Off Benefits . . . . . . . . . . . . . . . . . 12

BUDGET ASSUMPTIONS $\ldots \ldots \ldots \ldots \ldots \ldots \ldots \ldots \ldots \ldots \ldots \ldots \ldots \ldots \ldots$

THE MACRO-SCHEDULE $\ldots \ldots \ldots \ldots \ldots \ldots \ldots \ldots \ldots \ldots \ldots \ldots \ldots \ldots$

UNCERTAINTIES $\ldots \ldots \ldots \ldots \ldots \ldots \ldots \ldots \ldots \ldots \ldots \ldots \ldots \ldots \ldots \ldots \ldots$

MANAGEMENT DESIGN $\ldots \ldots \ldots \ldots \ldots \ldots \ldots \ldots \ldots \ldots \ldots \ldots \ldots \ldots \ldots \ldots$

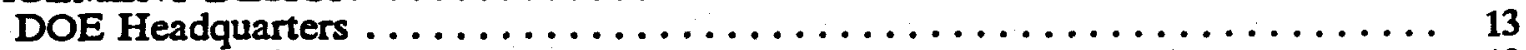

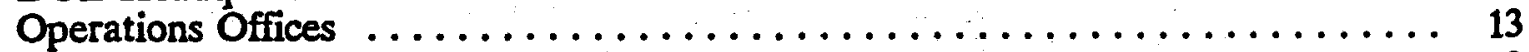

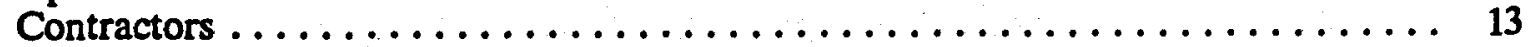

APPENDIX A: PRIMARY RESEARCH ACTIVTTIES OF THE GEOTHERMAL

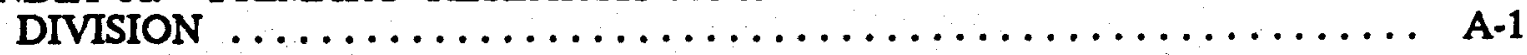

APPENDIX B: GEOTHERMAL PROGRAM MANAGEMENT MILESTONES . . . . . . B-1 


\section{BACKGROUND}

\section{Status of Geothermal Development}

Geothermal energy is commercially employed to produce electricity for utilities at 17 fields in California, Nevada, and Utah. Geothermal energy is a cost-effective and competitive resource at these locations with nearly $2800 \mathrm{MWe}$ of capacity in operation. The resource provides about $8 \%$ of the power currently used in California. Further power development appears imminent in Hawaii and the Pacific Northwest.

The annual geothermal energy use for direct geothermal heat applications in the U.S. is over 18 trillion Btu or the equivalent of over 5 million barrels of oil at $60 \%$ conversion efficiency. It is estimated that about 110,000 geothermal heat pumps are in use and rapid growth in this technology is anticipated. In addition, 25 geothermal municipal and institutional district heating systems are in operation; many structures are heated/cooled with individual systems, and a number of commercial/industrial enterprises operate economically with geothermal heat.

The geothermal power industry reports that the severe institutional impediments to geothermal development of the 1970's have largely dissipated. For example, the industry has acquired a good land position for development in the western states through an accelerated federal leasing program and many overlapping provisions in various federal and state environmental regulations have been modified to reduce unnecessary construction costs and lead times at no penalty to the environment.

\section{The Investment}

The Department of Energy (and its predecessors) has spent in excess of \$1.3 billion in support of geothermal development in this country both for power generation and direct use. Industry and utilities have spent in excess of an estimated \$5 billion for power projects alone.

In addition to expenditures for technology development, expenditures by both industry and government have been made to overcome institutional barriers to development. In the case of industry, early environmental and other regulatory requirements necessitated expensive remedial actions and loss of promising resource areas. In the case of the government, substantial effort was made to overhaul tax and regulatory aspects of geothermal development. Since 1982, virtually all of DOE's expenditures have been dedicated to improving technologies for locating and developing geothermal reservoirs and for managing the production of geothermal fluids and converting their thermal energy to electric power.

\section{Benefits}

The benefits of these investments are manyfold. First, there is an increase in the economic supply of geothermal energy to provide a benign energy source for power generation and direct heat applications. Second is a reduction in power demand through the widespread use of geothermal heat pumps and other direct heat uses. These applications, and the inclusion of geothermal energy in integrated resource planning, may relieve demand pressure on some utilities, providing an opportunity to defer new capacity. In addition, the advancements achieved through federal expenditures - both technical and institutional - continue to provide a favorable investment climate for geothermal technologies and improve the competitiveness of geothermal products and services to meet the 1995-2005 markets. 
The use of geothermal power by utilities resulted in a $\$ 125-\$ 250$ million cost-savings to consumers in 1988, primarily due to the low cost of power from The Geysers (CA). New hot water plants are providing customers with reliable power supplies with availability ratios second to none. A majority of these geothermal electric power generating plants are sited on federal leases, and in 1989, the latest year for which data are available, these leases returned some \$14 million in lease and rental fees to the federal government.

Further, in local air quality terms, a number of western metropolitan areas will be assisted in meeting regulatory requirements. Nationally and globally, use of geothermal resources increases the energy supply without detrimental environmental effects; reduces the demand for imported oil and frees some domestic oil for other uses, such as chemical feedstocks; and reduces the clearing of rain forests or burning of fossil fuels in many developing countries with large untapped geothermal resources.

Geothermal facilities also can co-exist compatibly with highly scenic and recreational values - e.g., the Mammoth Plant near Mammoth Lakes in the Mono-Long Valley area of California. This factor makes geothermal energy a prime candidate for increasing the power supply with the least impact in sensitive environments.

\section{Stakeholders}

The participants in geothermal development include utilities, field developers -- some of whom also own and operate power plants -- and other independent power producers. At The Geysers, 23 of 28 plants are owned by utilities - investor-owned and municipal -- while the hot water industry is dominated by independent power operators, and only two of 36 plants are utility-owned. In addition to utilities, the industry is an amalgam of oil companies, geothermal energy entrepreneurs, and a mix of partnerships formed by representatives of other industries and the financial community. A number of newcomers have no previous energy investment experience.

A wide range of service and supply companies provide valuable support to geothermal developers and operators. These companies are engaged in a multitude of activities needed to bring a geothermal project online, such as conducting geophysical and other geoscience surveys; providing drilling expertise; supplying chemicals, piping, and other materials; and manufacturing turbines.

Additional stakeholders include researchers and others in the R\&D community who are actively improving various geothermal-related technologies to advance geothermal development and the Public Utility Commissions and regulators whose efforts ultimately affect the utilization of the Nation's geothermal resources.

\section{Government's Role to Date}

The federal geothermal program was initiated in the early 1970's to investigate the feasibility of using this alternative energy source. The Atomic Energy Commission, the National Science Foundation through the Research Applied to National Needs program, and the U.S. Geological Survey were charged with directing the early resource and technical assessments. The program continued as a scientific/technical effort with only marginal commercialization interest until passage of the Geothermal Energy Research, Development, and Demonstration (RD\&D) Act of 1974.

Subsequently, a formal commercialization program was initiated, and from 1977 to 1981 its budget was by far the largest element of DOE's total geothermal funding. Commercialization embraced expenditures for the cost-shared demonstration plants at Baca, New Mexico, and Heber, California; 
a program to expedite direct use; cost-shared resource assessments by industry and the states; and studies on leasing, environmental regulation, and other institutional problems. The significance of these efforts is demonstrated by the fact that eight of 14 reservoirs explored under DOE's Industry. Coupled Drilling Program of the late 1970's are currently in production, and each is acknowledged to have additional undeveloped potential. A cost-shared inventory of low- and moderatetemperature resources in 22 states and cost-shared direct use demonstration projects led to an upsurge of these applications in the late 1970's; most projects that originated with DOE funds have since been expanded. Implementation of many of the recommendations made by the DOE-funded Interagency Geothermal Streamlining Task Force during that period have led to remedial regulatory and administrative changes that greatly reduced costs and accelerated geothermal development.

Commercialization dominated the program through 1983, reflecting the final federal outlays committed for the Heber plant. In 1981, however, a policy decision was made to rely on the market and on incentives of the National Energy Act of 1978 for geothermal energy commercialization, thus shifting the program's emphasis back to research and technology development.

In terms of site-specific results of government research, the technology for the economical use of hypersaline fluids in flash plants, developed at the cooperative government/industry Geothermal Loop Experimental Facility, is used today in six plants at the Salton Sea (CA) reservoir totalling $200 \mathrm{MWe}$ in capacity. This technology has also been the subject of intensive follow-up by industry and, if technologies are available for efficient management of this field, another $1800 \mathrm{MWe}$ may be developed. At Coso (CA), which today hosts $240 \mathrm{MWe}$ of geothermal power, the developer started with DOE-funded data in the early 1980's and built a successful exploration effort. In addition, previous research on dealing with high-temperature environments has led to the industrywide use of temperature-hardened materials and components. Even more important, in almost every instance of which the Geothermal Division is aware, industry development funds have been spent to further refine the research results.

With decreased budgets, the R\&D program of the 1980's was characterized by long-term, highrisk R\&D funded by the government and short-term efforts to encourage the commercial manufacture of the products of research, often cost-shared with industry. The government began to rely on industry facilities for testing new or improved equipment and materials developed by the DOE program. For example, Oxbow Geothermal Corporation provided existing field data and the use of their wells and geothermal field at Dixie Valley, Nevada, to DOE-sponsored researchers for an injection tracer test conducted to model fluid flow in the reservoir. More recently, industry has provided field operating data for use in validating or modifying reservoir models. For the past several years, hydrothermal R\&D has been guided by quantified cost-of-power objectives determined through the use of IMGEO ("Impacts of Geothermal Research"), a model which uses actual plant experience to simulate interactions among the components of a hydrothermal electric plant.

The federal role is now changing again to emphasize applications research and development activities while continuing some long-term, high-risk research. By working cooperatively with industry and utilities, technologies capable of tapping geothermal energy's vast potential will be available for deployment in the near-, mid-, and long-terms.

When the Office of Conservation and Renewable Energy was reorganized to create an end-use oriented structure, the geothermal research program was adapted to respond to the needs of the utility sector. Currently, the program's objectives are more specifically focused on developing 
additional energy supplies, reducing energy demand, reducing institutional barriers that constrain renewable technologies, and accelerating market penetration by new technologies. The Geothermal Division already has been cooperating with various utilities in expanding the use of geothermal heat pumps and incorporating geothermal energy into their integrated resource plans. Industry has also been exploring the use of geothermal energy for thermally enhanced oil recovery, the detoxification of pollutants, and other innovative applications subsequent to earlier DOE research. In the near future, Pacific Gas and Electric Company intends to participate, through cost-sharing, in research activities to develop small modular conversion systems, and the Bonneville Power Administration plans to develop three $10-\mathrm{MW}$ geothermal pilot plants.

Throughout the life of the federal program, R\&D for geopressured and hot dry rock resource applications has been almost exclusively a government function. Technology to harness these resources lies beyond the financial capabilities of the geothermal community, but the potential payoff in the long-term cannot be ignored. This approach is in accordance with the mandate of the RD\&D Act of 1974 to determine and improve the scientific, engineering, and economic feasibility of using energy from all types of geothermal systems.

Given the stage of geothermal development today, what is the rationale for continued federal technology research and development? For oversight of institutional impediments to geothermal growth? For transfer of advanced technologies to industry? For continued contributions to geothermal education?

The answers to these questions appear to encompass issues beyond oversight responsibility, technology transfer, and educational advancement. Without continued substantive federal involvement, geothermal energy will play a much smaller role as a competitive energy supply option. Overall, the geothermal industry is appreciably smaller than the industries that supply fuel and generate electric power from conventional energy sources. This situation leaves geothermal companies in a position where they lack the financial resources to wholly fund essential research. They are still unable to take the substantial investment risks that accompany major geothermal development. Also, potential markets for geothermal-generated power are often located some distance from the resource, and construction of transmission lines to tie into the grid are costly. Federal support stimulated the initial commercialization and expansion of the abundant moderatetemperature hydrothermal resources, both in terms of R\&D and institutional factors. That support must continue in order for geothermal resources to fulfill their potential as economic energy alternatives.

\section{THE VISION}

The challenge, or opportunity, confronting the Geothermal Division is to help increase the amount of our country's energy that can be economically recovered and used for beneficial purposes. Simply stated, our mission is to increase geothermal reserves, reserves being defined as that portion of the identified resource which can be extracted economically under existing conditions.

The most recent estimate of U.S. geothermal reserves is 5,000 MWe and consists of hydrothermal energy predominantly from identified and producing sites. Based on USGS criteria (Circular 790), these locations have the potential of generating 12,000-13,000 MWe. By continuing geothermal research activities at the current level and discovering additional geothermal fields, it is projected that 22,000 MWe of geothermal capacity can be available by 2030. A more aggressive exploration and $R \& D$ program could potentially result in $48,000 \mathrm{MWe}$ by 2030 . Increasing geothermal reserves is largely a function of technology advancements and economics; thus, when circumstances permit, geopressured and hot dry rock systems could also contribute to geothermal reserves. 


\section{Technology Development Needed for Power Generation/Energy Supply}

Expansion by the geothermal industry both within and beyond the 17 currently producing fields will require innovative technologies. There is little experience in this country in expanding the use of liquid-dominated fields that have been in production for several years. Thus, analytical tools are needed to determine the effects of existing operations on the reservoir and to optimize placement of new plants, new production wells, and new injection wells to reduce the risk of mismanagement or over-production of the reservoir.

In addition, while operations at The Geysers steam field always have been an industry pursuit, government should cost-share restoration of the productivity of the field for two reasons. First, The Geysers complex offers the first opportunity in this country to study the behavior of a mature geothermal field. Second, the success of The Geysers, and now its decline, are so well-known worldwide that maintaining confidence in this field is critical to ensuring confidence in all proven and yet-to-be-proven geothermal fields. The importance of The Geysers is further demonstrated by the degree of participation by both DOE and industry. In FY 1990, \$3.5 million in funds or inkind contributions were invested by industry; DOE provided $\$ 1.2$ million. For FY 1991, industry has earmarked \$4.5 million and DOE has budgeted \$2.5 million for cost-shared research at The Geysers. Investments of this magnitude are expected to continue until the field's problems have reached some resolution.

For expansion to new reservoirs, industry is seeking innovative methods to locate and characterize undiscovered hydrothermal reservoirs. The development of these new techniques will convert hypothetical "resources" into hard, proven "reserves," particularly those with no obvious surface manifestations of a subsurface heat source. Only one such area is in production today -- the Desert Peak field in Nevada.

While drilling technology is an integral part of all stages of geothermal development -- exploration, reservoir development, and production/injection -- the costs are still often 3 to 4 times those of oil and gas wells. Thus, new drilling technologies are needed to reduce the costs of exploratory wells to confirm hidden reservoirs and to increase the geologic data obtained from each well. In addition, such innovations would greatly improve the "dry holen ratio in fractured reservoirs and increase well productivity. This would cut the number of wells for each $100 \mathrm{MW}$ of installed power.

Increases in conversion efficiencies are needed to optimize the heat value of the resource and to offset large investments in finding and producing the resource. In addition, better modular technology than is available today will supply an enhanced means of testing new reservoirs, allowing early power production and cash flow, encouraging step-by-step development, and reducing financing costs.

If geopressured and hot dry rock resources are to be commercially developed in the future, the Geothermal Division must transfer the knowledge that will permit decisions about the economic competitiveness and reliability of these new energy sources. In the case of geopressured brines, industry needs an understanding of how geopressured reservoirs behave over extended periods of time (e.g., drive mechanisms), including the ability to predict reservoir characteristics (reservoir size and longevity, hydrocarbon content, salinity) with high confidence. For hot dry rock, future developers will need definitive information on thermal lifetime, flow impedance, water consumption rates, production fluid chemistry and temperatures, and energy productivity on an extended basis. 


\section{Potential Needs in U.S. Geothermal Infrastructure}

The U.S. geothermal industry currently operates in a relatively friendly infrastructure in terms of official and public acceptance with, at present, only one major site-specific exception in Hawaii. However, as use of this resource expands into new areas, assistance or support in outreach activities may be warranted to inform cognizant regulatory officials and/or the public as to the nature of the impact of geothermal development on their communities or region. For example, the prime geothermal prospect areas in Oregon lie in scenic national forests. As geothermal development begins to approach reality in this area, public concern and opposition has mounted. Through comprehensive public information programs, the U.S. Forest Service has undertaken to protect the multiple interests of the public, other forest users, and the geothermal community. Without this effort, geothermal development might not be able to expand into the Pacific Northwest.

The current favorable climate for development on federal land appears to be one result of earlier DOE outreach efforts to inform Forest Service personnel of the importance and benefits of geothermal energy. Those efforts showed that geothermal development can co-exist with competing interests in the forests. Consequently, the Forest Service has expedited decisions on lands to be leased for geothermal development. However, land use concerns, environmental mandates, and policy decisions at the federal and state levels will continue to affect geothermal development.

The industry itself appears to have overcome, at least for now, the problem of the remote location of many geothermal reservoirs, vis-a-vis, the availability of transmission lines. This is illustrated by the transmission line built specifically for the geothermal power plants operating in the Imperial Valley of California. Similarly, Oxbow Geothermal found the resource at Dixie Valley, Nevada, sufficiently attractive to build its own 220-mile transmission line to a tie-in with existing lines. The key here, however, is a large, high-quality resource; lesser resources may not justify such expenditures. Eventually, some provision for guaranteed transmission access may be warranted at the utility, state, or regional level.

Changes in the marketing of geothermal power appear to be on the horizon through load-following operations. While hot geothermal wells cannot be shut-in for extended periods without risk of damage, the industry believes it has the capability to tailor production to meet variable power demands. One utility at The Geysers has been practicing load-following for over a year. Whether any DOE involvement will be sought by the industry as it expands from strictly baseload operations to supporting intermittent or peaking modes of operation is unclear at this time.

\section{Obstacles to Geothermal Development}

During the National Energy Strategy process, geothermal advocates noted that a concerted R\&D effort by DOE is needed to solve technology problems which are hampering increased geothermal use. These problems were alluded to in the previous discussion. In addition, the following obstacles to geothermal development were identified:

- Energy prices have dropped so low that there are no incentives to make the large investments required to find and develop new resources. The effects of recent events in the Middle East on oil prices are not yet clear.

- The market for geothermal power is primarily in the western states where there is currently an oversupply of generating capacity.

- Present tax regulations do not provide sufficient encouragement to geothermal development. 
- Present energy policies do not reflect the external costs of energy transformation and use, or consider total fuel-cycle costs. Incentives for development of resources that are environmentally advantageous are needed.

- Denial by major utilities of free access to transmission lines and wheeling rights.

- Failure to plan cooperatively for geothermal development -- e.g., through unitization.

- Foreign government incentives for exports (i.e., tied aid) reduces competitiveness of U.S. geothermal products and services in international markets.

\section{Options for Removal or Alleviation of Obstacles}

The reorganization of DOE's Office of Conservation and Renewable Energy is designed to accelerate the market penetration of new technologies to suitable end-use applications in several energy sectors. Applications research and development activities to "push" technologies to commercial maturity for both demand-side and supply-side approaches to energy supply are being emphasized under this arrangement. Reducing institutional and economic barriers allows market "pull" to enhance the use of these technologies. Within the new structure, the Office of Utility Technologies has been created to play a key role in addressing the challenges and opportunities facing the electricity sector, including the use of geothermal resources for power generation.

The reorganized renewable energy program is already focusing on the known obstacles to geothermal development. For example, for the first time, an effort is being made to integrate energy and environmental policies. The program foresees a new working relationship with the Environmental Protection Agency, particularly in the arena of pollution prevention through policies that will encourage greater use of renewable energy. Consideration is being given to performing complete fuel-cycle cost analyses for energy systems as a whole which evaluate the economic, social, and environmental costs of competing technologies to help the private sector better assess the most cost-effective allocation of resources to meet energy needs. The new Clean Air Act amendments are being analyzed to determine their potential effect on geothermal energy in the U.S. power market. The impacts are expected to be economically favorable as the costs of more stringent regulations are applied to fossil-fired plants.

New programs to address issues regarding transmission pricing and access can make major strides toward maximum utilization of transmission systems and various types of tax incentives are being analyzed to determine their potential impact on energy technologies. Amendments to PURPA have been enacted in November 1990 which remove the cap on plant size for all energy technologies covered by the Act.

Legislation entitled the "Renewable Energy and Energy Efficiency Technology Competitiveness Act of 1989," signed by the President in December 1989, supports the goals of DOE's Renewable Energy Programs. It calls for authorization of renewable energy R\&D budgets for three fiscal years at a time, a move that would lend considerable stability to research programs, and one which has long been advocated by the industry. In addition, the Act addresses the desire of the U.S. industry to increase its competitiveness in overseas markets. It directs the interagency Committee on Renewable Energy Commerce and Trade (CORECT) to "establish in consultation with representatives of affected industries, recommended administrative guidelines for federal export loan programs to simplify application by firms seeking export assistance for renewable energy technologies from agencies implementing such programs." 


\section{Key Participants Needed for Success}

All elements of the U.S. geothermal community contribute to the success of the federal R\&D program, as well as helping to assure an infrastructure in which geothermal development can flourish as more market opportunities become available. The community is an especially closeknit one and cooperation is the norm. This group includes other federal agencies .- the U.S. Geological Survey, the Bureau of Land Management, the U.S. Forest Service -- state energy and resource agencies, the national laboratories, utilities, and industry.

Two unique DOE/industry organizations, the Geothermal Drilling Organization (GDO) and the Geothermal Technology Organization (GTO), are critical to the successful transfer of technology to the marketplace. These organizations function similarly except that the interests of the GDO are centered on geothermal drilling technologies, whereas the GTO focuses on technology development related to reservoir performance and energy conversion. Both organizations support projects designed to market the products of research. Projects are jointly funded by DOE and the participating industry partners, with industry providing at least $50 \%$ of the total cost. Just recently, the GDO completed improvements to a rotary head seal and transferred the technology to industry for commercial production. In addition, both organizations frequently provide test sites for investigating new technology and methods. For instance, GTO members provided the premises for a cooperative research effort to monitor signals from an advanced seismic array at The Geysers.

\section{THE OBJECTIVES}

The major objectives of the Geothermal Division for the FY 1992-1997 planning period are as follows:

\section{Near-Term (until 1995)}

- Reverse the pressure decline at The Geysers steam field in California and restore lost productivity by developing and testing improved reservoir management techniques in cooperation with industry.

- Test the hot dry rock reservoir at Fenton Hill, New Mexico, to evaluate its performance characteristics over an extended period of time.

- Improve the understanding of how geopressured reservoirs behave by decreasing uncertainty in reservoir performance to enable predictions of characteristics (i.e., reservoir size and longevity, hydrocarbon content, salinity) with $90 \%$ confidence over a 10-year operating period.

- Improve efficiency of binary cycle systems by $25-30 \%$ through experiments on mixtures of working fluids, supercritical vaporization, integral condensation, and supersaturated expansion in binary turbines.

- Decrease front-end costs of geothermal heat pumps by improving ground loop installation technology.

- Reduce the downtime due to lost circulation during drilling by developing an expert system, various types of packers, and advanced detection tools. 
Mid-Term (1995-2010)

- Develop and test innovative exploration methods to locate and characterize the undiscovered hydrothermal reservoirs.

- Increase a reservoir's economic value by conducting research on how to operate a geothermal reservoir in a peaking mode.

- Reduce the number of needed exploratory wells by $15 \%$ and the dry hole ratio in fractured reservoirs by $20 \%$ by developing advanced sensing tools, improved dualwell seismic techniques, and fiber optic technology.

- Reduce well costs and extend well life using advanced non-metallic well casing liners and materials for the in situ conversion of drilling fluids into cements.

- Reduce plant maintenance costs by $10 \%$ by predicting scale formation from geothermal brines and developing low cost, environmentally sound waste disposal processes.

- $\quad$ Reduce front-end costs of power plants by identifying high-efficiency standardized modular power plant technology.

\section{Long-Term (past 2010)}

- Identify, in cooperation with industry, hidden geothermal resources and increase the number of sites for future development through the application of advanced exploration technology and confirmatory drilling.

- Determine if the performance of the Fenton Hill Phase II reservoir, when considered as a modular unit in a commercial-scale project, could support production of electricity at an economical busbar cost.

- Improve the ability to locate fractures in hot dry rock environments.

An overall technology cost objective for hydrothermal of 3-7 cents $/ \mathrm{kWh}$ for the mid-term was determined through the use of a quantitative cost-of-power model (IMGEO, "Impacts of Geothermal Research"). The model simulates interactions among the components of a hydrothermal electric plant and enables a comprehensive cost analysis of impacts from each element of the hydrothermal research program. For example, the impact on the cost of power of a 20\% decrease in well drilling costs can be determined. Sensitivity analyses can be conducted to determine which technology improvements will have the greatest overall impact. Models for geopressured and hot dry rock resources are under development.

\section{THE STRATEGY}

The Geothermal Division has implemented a strategy which aims to increase the Nation's energy supply by markedly expanding the economically recoverable hydrothermal resource base through the discovery of new reservoirs, the development of advanced drilling techniques and enhanced energy conversion systems, and the improvement of reservoir management methods. The strategy also strives to reduce power demand through the widespread use of geothermal heat pumps and other direct heat uses. Research activities which can be cost-shared with industry partners as well 
as other funding agencies will be emphasized to assist industry in eliminating near-term technical obstacles to geothermal development and exploitation. Efforts enabling geothermal energy to contribute to integrated resource planning activities will also be encouraged.

\section{Primary Research Activities by Year and Expected Incremental Products}

The primary research activities for the base-level funding program for FY 1992-1997 are identified in Appendix A for Hydrothermal Systems, Geopressured Research, and Advanced Systems, along with the expected incremental products of the research. These program activities are designed to accomplish the three levels of program objectives defined in an important companion program document entitled Programmatic Objectives of the Geothermal Division, U.S. Department of Energy (1989, Revised). The objectives have been established such that the achievement of research objectives (Level III) results in improvements in the various geothermal-related technologies and these advancements, in turn, translate into cost adjustments (Level II objectives) that reduce the overall cost-of-power (Level I objectives). As the objectives document also points out, analysis of technology performance is a critical step in determining geothermal objectives. Until recent years, the performance analysis was largely qualitative, necessitating considerable subjective judgment on the part of geothermal program managers. Now, however, the subjective approach has been modified by the introduction of the quantitative, cost-of-power IMGEO model.

The Level I objectives allow analysts and decision makers to estimate the future cost of power from geothermal energy systems. At this level, the objectives are expressed in terms of reducing the lifecycle costs of energy from a typical geothermal energy production project (e.g., a binary electric power plant including its geothermal fluid supply).

The basis for the Level I hydrothermal objective is that the technology is not available for economic exploitation of the large bulk of the identified hydrothermal reservoirs in this country where the temperature is below the economic range of flash plants. Some very small binary units -- most around $2 \mathrm{MWe}$ or less in capacity - are operating successfully with low-temperature brines. However, in these cases, economics are dictated by size and very favorable site-specific conditions -- e.g., sufficient heat at very shallow depths, use of existing wells -- that are not generally available. The success of these small plants is to be applauded; however, a multiplicity of installations of this size will not permit geothermal energy to reach its full potential as a viable energy supply option. While industry will profitably use small capacity facilities as "ice breaker" plants at undeveloped reservoirs, and such units are very useful in filling small incremental power demand, more favorable economics for larger plants (e.g., 10-100 MWe) are the key to meaningful expansion in geothermal utilization. To achieve the cost goal, it will be necessary to bring about economies across the board -- from reservoir characterization to drilling and field development to the binary power cycle itself.

These economies are the focus of the Level II hydrothermal objectives established through the use of the IMGEO model. This level of objective gives government and industry managers an impression of how much improvement is likely to occur within major project components as a result of federally funded research.

The Level III objectives prescribe the technical direction of individual research projects. They facilitate communication among engineers and scientists and comprise the technical yardsticks by which progress can be measured.

Cost-of-energy models equivalent to the IMGEO hydrothermal model are not yet available for geopressured brines or hot dry rock. The objectives for these resource types, to which the R\&D 
activities in Appendix $A$ are addressed, were set by Geothermal Division staff through consultation with DOE field R\&D managers and industry specialists.

Industry is actively participating in the planning and implementation of the R\&D program objectives. Industry's response to the achievement of objectives -- i.e., whether or not industry expands beyond currently known hydrothermal reservoirs -- will be the final test of the success of this plan.

\section{Monitoring of Infrastructure Conditions}

The Geothermal Research, Development, and Demonstration Act of 1974 provides the authority for the Geothermal Division to identify "social, legal, and economic problems associated with geothermal development (both locally and regionally) for the purpose of developing policy and providing a framework of policy alternatives for the commercial utilization of geothermal resources." The Geothermal Division has exercised this authority in the past, largely through funding the Interagency Geothermal Streamlining Task Force and the Barriers Panel of the Interagency Geothermal Coordinating Council.

And, as discussed previously, the Geothermal Division, and its predecessors, have maintained close contact with all elements of the infrastructure in which the geothermal industry -- both utilities and developers - operates. Thus, mechanisms are in place to monitor the status of the infrastructure elements and to identify problem areas as they develop. There is regular -- formal and informal, scheduled and unscheduled - dialogue among the entities, and the Geothermal Division is kept abreast of interaction between industry and its infrastructure.

Regular interaction with state energy offices is maintained; frequent inquiries are directed to state regulatory agencies to ascertain their views on compliance by the geothermal industry; and dialogue continues between the Geothermal Division and regional power agencies such as the Bonneville Power Administration. Funding of geothermal research programs at Stanford University and other academic institutions provides "hands-on" experience for students who provide the professional workforce for the geothermal industry. In addition, the Geothermal Division participates in and actively supports the public information and educational programs of the Geothermal Resources Council.

Thus, little need is foreseen for future major intervention by DOE in the forces that shape the environment of geothermal development. That effort is primarily behind us, although problems could arise that would deserve special attention.

\section{Indications of Progress}

Due to the nature of geothermal operations -- and the variability of the resource -- progress is not measured by "overnight" successes. Rather, progress toward competitiveness with other fuels is based on an evolutionary process, consisting of incremental improvements in methods, equipment, and materials, marked intermittently by exceptional advancements.

For example, $R \& D$ in reservoir technology to characterize subsurface geologic structures and the occurrences of viable resources within them is an ongoing process, requiring years of field operating data to evaluate, verify, or modify characterizations drawn from earlier data. However, recent injection tests of new organic tracers confirmed the calculations of a numerical reservoir model on tracer breakthrough, thus providing significant evidence of a research success. 
The overall results of the research activities outlined in this plan will be measured by reductions in the cost of geothermal power as determined by the IMGEO cost model, appropriately adapted to analyze hydrothermal, geopressured, and hot dry rock resources. The actual cost benefits will accrue incrementally in subsequent years as industry adopts the new technology and gains operating experience with it.

\section{Ancillary or Spin-Off Benefits}

Based on previous experience, the oil and gas industry and others can be expected to benefit from various advancements in reservoir technology and innovative drilling techniques developed through geothermal R\&D. The development of cements and materials for bonding high-temperature elastomers to metal can be expected to find application wherever heat and/or corrosion create major problems in the performance and durability of materials. In the waste and brine modeling areas, techniques developed for geothermal activities can be applied to a host of other industries, such as mining and environmental clean-up. Additionally, advancements in binary technology should have broad application to various industrial operations.

\section{BUDGET ASSUMPTIONS}

Renewable energy technologies received a great deal of visibility and support during the public hearing process for the National Energy Strategy. As a result, while the Department continues to analyze and evaluate the many energy options proposed, Secretary Watkins designated renewable energy for "fast track" consideration among the policy choices. This action, combined with greater budgetary support, indicates an enhanced emphasis on renewable energy programs. Recent threats to imported oil supplies appear to have further solidified public support for more expeditious development of renewable energy technologies.

The Geothermal Division has proposed two major scenarios for the FY 1992-1997 planning period. The base case scenario entails activities to achieve the current research objectives and assumes a 6-year budget of $\$ 148$ million and Division staff of 12-14 full-time equivalents (FTE). Under the enhanced scenario, new initiatives for industry-coupled drilling and resource confirmation, geothermal heat pump installation, advanced drilling technology and modular energy conversion are pursued; hot dry rock demonstration projects are initiated earlier to accelerate commercial development and potentially double geothermal power on-line after the year 2010. A 6-year budget of \$242 million and Geothermal Division staff of 17-18 FTE are assumed. Table 1 presents the resource plan for the geothermal program for the FY 1992-1997 planning period.

\section{THE MACRO-SCHEDULE}

Technical milestones have been established for each of the research tasks in the R\&D program. These milestones are used as targets and provide a basis for evaluating the accomplishments made to date. Periodic reevaluation is conducted to ensure that the milestones meet the latest program objectives and consider current budgetary constraints. The key milestones for the base case and new initiatives for FY 1992-1997 are shown in Table 2. A more detailed set of milestones is provided in Appendix B.

\section{UNCERTAINTIES}

Given the risks and uncertainties of research, the objectives expressed in this plan may be subject to change. In addition, the potential for changes in policy directives, industry needs, new concepts for technology improvement, and funding levels requires that the Geothermal Division maintain a degree of flexibility in its R\&D approach. 
Table 1

GEOTHERMAL RESOURCE PLAN*

\begin{tabular}{|c|c|c|c|c|c|c|c|}
\hline $\begin{array}{l}\text { Resource Plan } \\
\text { (Dollars in Millions) }\end{array}$ & FY92 & FY93 & FY94 & FY95 & FY96 & FY97 & Total \\
\hline Base Budget & 19.2 & 23.2 & 24.4 & 25.6 & 27.0 & 28.3 & 147.7 \\
\hline Enhanced Budget & - & 17.2 & 18.0 & 18.9 & 19.8 & 20.8 & 94.7 \\
\hline TOTAL & 19.2 & 40.4 & 42.4 & 44.5 & 46.8 & 49.1 & 242.4 \\
\hline
\end{tabular}

* Budget figures are for internal planning purposes. They have not been approved as U.S. Government budget figures or projections.

\section{MANAGEMENT DESIGN}

\section{DOE Headquarters}

The Geothermal Division is responsible for overall program management and operates under the administrative oversight of the Office of Renewable Energy Conversion under the Office of the Deputy Assistant Secretary for Utility Technologies. With the assistance of these offices, the Geothermal Division Director implements energy policy at the program level and allocates the necessary technical and budgetary resources for program activities.

\section{Operations Offices}

Under the guidance and leadership of the Geothermal Division, field organizations implement program plans, execute prime contracts for research, direct contractors and review their performance, and provide the Geothermal Division with recommendations on program needs and direction.

\section{Contractors}

Actual implementation of the geothermal research program is performed by contractors, including the national laboratories, universities, and industry. The participating contractors are responsible for the conduct and day-to-day management of the research activities.

Substantial contractor investment in human, technological, and analytical resources, as well as for laboratory equipment and facilities, has been instrumental in establishing institutions specializing in various aspects of geothermal research. Over the years, unique geothermal expertise has evolved at Sandia National Laboratories, Idaho National Engineering Laboratory, Lawrence Berkeley Laboratory, Los Alamos National Laboratory, the University of Utah Research Institute, Stanford University, and Brookhaven National Laboratory. 
Table 2

\section{GEOTHERMAL KEY MILESTONES}

\section{Becthermal Enorgy Systoms - Base Case}

\begin{tabular}{|c|c|c|c|c|c|c|}
\hline \multirow{3}{*}{ Reservoir Technology } & Pres & mos & Fra & mos & $m$ & $m$ \\
\hline & & & & & & \\
\hline & & is & 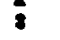 & & 4 & \\
\hline Advancod Drilling & & & 8 & & & \\
\hline Converston Tectinology & & & & & & \\
\hline Ceopreseured and Hot Dry Rock & & & & & & \\
\hline
\end{tabular}

1.2 Test Now Injection Technology at The Coysers; Complete Study of Peaking Mode Operation

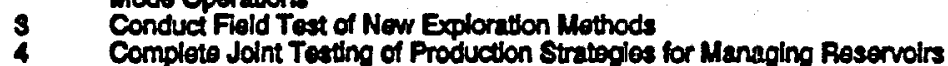

6 Complete Development of Emplacement System for Geothermal Heat Pump

Ground Loops

6 Fiold Test Weasurement-Whilo-Drilling Tools and Fiber Optic System

7,8 Complete Studies to Improve Binary Cyde Technology, Develop Elastomerle Well Casing Liner

9 Buld Commercial-scate Bioreactor with Industry

10,11 Complete Sclentinc Tosts of Geoprosured Resenvira; Complets Long-Term Fow Test of the Hot Dry Pock Reservolr

Goothermal Enorgy Syctems - Enhanced Case

\begin{tabular}{|c|c|c|c|c|c|c|}
\hline & me & mos & Pres & mos & mi & $\mathbf{m m}$ \\
\hline \multicolumn{7}{|l|}{ Reserves Conilmation } \\
\hline \multicolumn{7}{|l|}{ Innovattvo Drilling } \\
\hline \multirow{2}{*}{\multicolumn{7}{|c|}{ Goothermal Heat Pumpe }} \\
\hline & & 2 & 20 & & & \\
\hline \multicolumn{7}{|l|}{ Modular Conversion } \\
\hline Geoprasesured and Hot Dry Rock & & & & & Lूro & \\
\hline
\end{tabular}

1 Conduct Fild Survere and Exploratory Drilling af Selected shos

2 Completo Cost-Shered Dilling of Mast Favorable sties

3 Conduct Cost-Shered Drling Uaing Niow Technology

4 Tranefer Technology os induetry

5 Conduct Nationa Uullties Awareneas Campalon

6 Demonetrati Ono-Dey installation of Readdental Units in Cooperation with Industry

Beoin Cout Shared Prolect Uaing Innovative Conversion Syatem

Field Teet Protorypo syatem

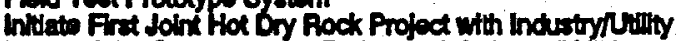

indate doint Geopreasured Project with industryntilitios 


\section{Appendix A}

PRIMARY RESEARCH ACTIVITIES OF THE

GEOTHERMAL DIVISION FOR FY 1992-1997

AND EXPECTED RESULTS

- BASE PROGRAM ONLY -

\section{PROGRAM ELEMENT}

\section{HYDROTHERMAL RESEARCH}

\author{
Reservoir Technology
}

\section{RESEARCH ACTIVITIES}

Work with utilities and field operators at The Geysers to test and evaluate water injection strategies for maximum energy recovery.

Field test surface-based high frequency seismic monitors for accurate measurement of fracture planes in The Geysers.

Determine basic thermodynamics of hydrogen chloride gas in steam.

Investigate the mechanism of water adsorption on fractured rock surfaces.

Conduct joint ventures with industry to select the most innovative exploration methods and implement the best exploration techniques.

Actively involve industry in technology development to produce the new generation of instruments necessary to discover hidden geothermal systems.

\section{EXPECTED RESULTS}

Determination of the most effective method of water injection to reverse the pressure decline at The Geysers and return the steam field production closer to the installed 2,000 MWe capacity; if successful, extension of reservoir lifetime by an order of magnitude.

Ability to locate major producing zones and reduce the risk and cost associated with drilling production wells.

Ability to control $\mathrm{HCl}$ corrosion in valves and surface pipes at The Geysers and other geothermal fields.

Ability to determine water saturation in reservoir fractures and the longevity of production.

Characterization of the large number of undiscovered geothermal resources in the U.S., building an inventory of sites for future industry development.

Enhanced superiority of U.S. industry in the international market for geothermal exploration and a competitive advantage for U.S. companies. Increased effectiveness of exploration tools and methods. 


\section{Appendix A}

PRIMARY RESEARCH ACTIVITIES OF THE

GEOTHERMAL DIVSION FOR FY 1992-1997 AND EXPECTED RESULTS

- BASE PROGRAM ONLY -

\section{PROGRAM ELEMENT}

Reservoir Technology (Continued)

Hard Rock Penetration reservoir simulation that combines

\section{RESEARCH ACTIVITIES}

In cooperation with the Geothermal Technology Organization, conduct industrydirected, joint-venture research to design the production wells and methods needed to operate a geothermal reservoir as a loadfollowing energy source.

Investigate the development of integrated hydrology and geochemistry in a single computer model.

Publish a collection of geothermal development case studies based on geothermal systems in the western U.S.

Transfer to industry technology for emplacing encapsulated cements and bridging materials to control lost circulation; develop and field test an expert system for lost circulation operations; field test the drillable straddle packer, porous packer, velocity-level flow tools, and borehole televiewer loss-zone characterization techniques.

Conduct field tests to compare production in large and small wellbores; build and test PDC coring bits; develop and field test slimhole coring exploratory drilling system; initiate development of measure-whilecoring system.

\section{EXPECTED RESULTS}

Significantly increased economic value of reservoirs through the ability to operate in a peaking mode.

Ability to track the migration of injected geothermal fluids and to predict their thermal and chemical changes in both vapor- and liquid-dominated systems.

Documented experiences of geothermal development in active, producing fields.

Reduction of $80 \%$ in downtime due to lost circulation episodes.

Development of relatively inexpensive coring holes which can assess reservoir productive capacity at half the cost of conventional wells. 


\section{Appendix A}

PRIMARY RESEARCH ACTIVITIES OF THE

GEOTHERMAL DIVISION FOR FY 1992-1997 AND EXPECTED RESULTS

- BASE PROGRAM ONLY --

\section{PROGRAM ELEMENT}

Hard Rock Penetration (Continued)

\section{RESEARCH ACTIVITIES}

Field test with industry advanced modular downhole memory tools and develop borehole instruments with industry.

Design drilling hardware for emplacement of vertical heat exchangers for geothermal heat pumps.

Place new rotary head seal into commercial application through the Geothermal Drilling Organization.

Begin new GDO projects on near-term technology improvements that are selected and cost-shared by industry on a 50-50 basis.

Begin adapting subsurface dual-well seismic technology to locate fractures.

Develop fiber optic cables and sensors for high-temperature (above $300^{\circ} \mathrm{C}$ ) logging.

Test supersaturated expansions in binary cycle turbines.

Document field tests of heat-resistant, lightweight cements and complete technology transfer.

Perform laboratory evaluations of chemical systems that will bond elastomers to steel.

\section{EXPECTED RESULTS}

Reduction of $15 \%$ in number of exploratory wells needed.

Expansion of cost-effective market penetration of geothermal heat pumps in higher density urban markets.

Increased reliability and reduced costs of rotary head seals for the geothermal and oil and gas industries.

Accelerated technology advancement and technology transfer.

Reduction in dry hole ratio in fractured reservoirs by $20 \%$.

Reduction in the number of exploratory wells needed through advanced measurement techniques.

Potential $5 \%-10 \%$ improvement in advanced binary plant performance.

Development of materials which can be used in the completion of geothermal wells.

Reduce cost of wells by the availability of advanced drilling equipment. 
Appendix A

PRIMARY RESEARCH ACTIVITIES OF THE

GEOTHERMAL DIVISION FOR FY 1992-1997

AND EXPECTED RESULTS

- BASE PROGRAM ONLY -

\section{PROGRAM ELEMENT}

Conversion Technology (Continued)

\section{RESEARCH ACTIVITIES}

Measure the resistance of ceramic-based cements to scaling and corrosion under simulated conditions at $300^{\circ} \mathrm{C}$.

Measure durability, pumpability, and density of materials that function as drilling fluids, but harden like cements when they enter fractures in rock formations.

Extend and refine existing brine chemistry model to include new experimental data to improve the capability to predict scaling tendency of geothermal brines and apply model to assist industry in solving on-site problems.

Continue development of a system to detoxify geothermal wastes with bacteria; design continuous process prototype for commercial geothermal site; examine process economics.

Test advanced heat rejection system.

Develop advanced elastomers and chemical coupling systems.

Develop advanced non-metallic well casing liners.

\section{EXPECTED RESULTS}

Extension of casing life by 10 years, costing one-third as much as metal alloys.

Commercialization of reliable in- situ lost circulation materials.

Reduction in plant maintenance costs by $10 \%$.

Potential for over $80 \%$ reduction in waste disposal costs.

Reductions in consumptives water use for heat rejection.

Reductions in costs and environmental impacts of drilling tools and safety-related devices.

Reduction in well costs and extension of well life. 


\section{Appendix A}

PRIMARY RESEARCH ACTIVITIES OF THE

GEOTHERMAL DIVISION FOR FY 1992-1997 AND EXPECTED RESULTS

-- BASE PROGRAM ONLY --

\section{PROGRAM ELEMENT}

\section{GEOPRESSURED RESEARCH}

\section{Well Operations}

Geosciences and Engineering Support

\section{RESEARCH ACTIVITIES}

Shut-in Pleasant Bayou well for pressure buildup.

Flow test Hulin well, then plug and abandon well or transfer to industry.

Complete scientific tests at Pleasant Bayou well site and analyze data.

Continue development of geologic models of Hulin area using recently acquired seismic data to better define reservoir boundaries and to ascertain whether gas cap is in hydraulic communication with the production.

Continue monitoring of surface and ground water, microseismicity, and subsidence at well sites.

Measure and interpret aromatic hydrocarbons at Hulin.

Interpret Hulin flow test data.

Coordinate final research reports.

\section{EXPECTED RESULTS}

Validation of reservoir model.

Determination of reservoir characteristics.

Identification of reservoir drive mechanisms and determination of the reservoir's longterm production capability.

Refinement of Hulin site geology.

Verification of no environmental effects from geopressured well testing activities.

Determination of the source and flow mechanism of aromatic hydrocarbons.

Validation of reservoir model and determination of the reservoir's long-term production capability.

Publication of final research reports in peerreviewed journals. 


\section{Appendix A}

PRIMARY RESEARCH ACTIVITIES OF THE

GEOTHERMAL DIVISION FOR FY 1992-1997 AND EXPECTED RESULTS

- BASE PROGRAM ONLY --

\section{PROGRAM ELEMENT}

\section{ADVANCED SYSTEMS - HOT DRY ROCK}

Phase II Energy Extraction System

Phase II Ancillary Activities

Reservoir Engineering

\section{RESEARCH ACTIVITIES}

Conduct long-term flow test (LTFT) and analyze data.

Operate reservoir under alternative conditions.

Secure water supplies to accommodate LTFT.

Collect and evaluate environmental monitoring data.

Verify behavior of diagnostic tracers.

Continue microseismic monitoring and improve 3-D models of reservoir performance using seismicity and tracer data.

\section{EXPECTED RESULTS}

Estimation of thermal lifetime; determination of reservoir productivity; compilation of reliable record of HDR engineering, operational, and maintenance factors, especially water consumption; validation of the commercial viability of HDR.

Definition of governing criteria for optimum productivity.

Maintenance of sufficient water needed for the LTFT.

Verification of the absence of effects from sustained reservoir operations.

Demonstration that tracers can predict reservoir thermal lifetime for $10-20$ years into the future.

Determination of reservoir expansion parameters and improved accuracy of reservoir mapping technology for easier development of new HDR systems. 


\section{Appendix A}

PRIMARY RESEARCH ACTIVITIES OF THE

GEOTHERMAL DIVISION FOR FY 1992-1997

AND EXPECTED RESULTS

-. BASE PROGRAM ONLY -

\section{PROGRAM ELEMENT}

Reservoir Engineering (Continued)

Technology Applications

\section{RESEARCH ACTIVITIES}

Extend modeling analysis to multi-well, multi-reservoir configurations that simulate full-scale commercial systems.

Conduct mineral dissolution studies.

Investigate zone isolation and impedance reduction technology.

Conduct technology transfer activities in cooperation with the utility sector.

Evaluate enhanced power production modes.

\section{EXPECTED RESULTS}

Enhancement of efficient reservoir operational modes and improved accuracy of forecasting production and cost.

Prediction of changes in flow impedance.

Advanced techniques for reservoir enhancement and multi-reservoir facilities.

Dissemination of HDR technology to the private sector.

Determination of alternative modes of economic reservoir production. 


\section{Appendix B}

GEOTHERMAL PROGRAM MANAGEMENT MILESTONES

FY 1992 - FY 1997

- BASED AND ENHANCED PROGRAMS -

\begin{tabular}{|c|c|c|c|c|c|c|c|c|}
\hline & \multicolumn{3}{|c|}{ FY 1992} & \multirow[b]{2}{*}{ FY 1993} & \multirow[b]{2}{*}{ FY 1994} & \multirow[b]{2}{*}{ FY 1995} & \multirow[b]{2}{*}{ FY 1996} & \multirow[b]{2}{*}{ FY 1997} \\
\hline MILESTONE & 2 & 3 & 4 & & & & & \\
\hline \multicolumn{9}{|l|}{ HYDROTHERMAL SYSTEMS } \\
\hline \multicolumn{9}{|l|}{ Reservoir Technology } \\
\hline \multicolumn{9}{|c|}{ Release full documentation of completed tracer tests. } \\
\hline \multicolumn{9}{|c|}{$\begin{array}{l}\text { Initiate analysis of core from phase II drilling of Long Valley } \\
\text { Experimental Well. }\end{array}$} \\
\hline \multicolumn{9}{|c|}{$\begin{array}{l}\text { Conduct cost-shared seismic experiments in Long Valley } \\
\text { Experimental Well. }\end{array}$} \\
\hline \multicolumn{9}{|c|}{$\begin{array}{l}\text { Initiate joint, cost-shared testing of new, innovative exploration } \\
\text { methods. }\end{array}$} \\
\hline \multicolumn{9}{|c|}{$\begin{array}{l}\text { Gather fundamental geochemistry data for interpretation and } \\
\text { inclusion in reservoir simulation. }\end{array}$} \\
\hline \multicolumn{9}{|c|}{$\begin{array}{l}\text { Include geochemistry in current reservoir simulation programs } \\
\text { to better predict reservoir lifetime. }\end{array}$} \\
\hline \multicolumn{9}{|c|}{$\begin{array}{l}\text { Complete new analysis and interpretation of existing exploration } \\
\text { data and select regional exploration areas for focused effort. }\end{array}$} \\
\hline \multicolumn{9}{|c|}{ Complete development of second generation chemical tracers. } \\
\hline \multicolumn{9}{|c|}{$\begin{array}{l}\text { Test new injection tochnology, with industry, to efficiently } \\
\text { recycle scarce available water at The Geysers field. }\end{array}$} \\
\hline Complete study of peaking mode operations. & & & & $\bullet$ & & & & \\
\hline
\end{tabular}




\begin{tabular}{|c|c|c|c|c|c|c|c|c|c|}
\hline \multirow[b]{2}{*}{ MILESTONE } & \multicolumn{4}{|c|}{ FY 1992} & \multirow[b]{2}{*}{ FY 1993} & \multirow[b]{2}{*}{ FY 1994} & \multirow[b]{2}{*}{ FY 1995} & \multirow[b]{2}{*}{ FY 1996} & \multirow[b]{2}{*}{ FY 1997} \\
\hline & 1 & 2 & 3 & 4 & & & & & \\
\hline \multicolumn{10}{|l|}{ Reservoir Technology (Continued) } \\
\hline \multicolumn{10}{|l|}{ Conduct field surveys and exploratory drilling at selected sites. } \\
\hline \multicolumn{10}{|l|}{$\begin{array}{l}\text { Conduct field test, with industry, of new exploration } \\
\text { methodology. }\end{array}$} \\
\hline \multicolumn{10}{|l|}{$\begin{array}{l}\text { Develop integrated, comprehensive exploration model of } \\
\text { geothermal fields. }\end{array}$} \\
\hline \multicolumn{10}{|l|}{$\begin{array}{l}\text { Conduct joint field tests of second generation chemical tracers } \\
\text { for determining flow paths in geothermal reservoirs. }\end{array}$} \\
\hline \multicolumn{10}{|l|}{$\begin{array}{l}\text { Develop tracking methodology to account for disposition of all } \\
\text { injected water in geothermal developments. }\end{array}$} \\
\hline \multicolumn{10}{|l|}{$\begin{array}{l}\text { Initiate development of reservoir computer simulation which } \\
\text { includes geochemistry. }\end{array}$} \\
\hline \multicolumn{10}{|l|}{$\begin{array}{l}\text { Complete joint regional exploration of initial areas and target } \\
\text { deep drilling. }\end{array}$} \\
\hline \multicolumn{10}{|l|}{$\begin{array}{l}\text { Complete joint development, with industry, of automated well- } \\
\text { field control for fast response to energy needs. }\end{array}$} \\
\hline \multicolumn{10}{|l|}{$\begin{array}{l}\text { Complete joint, cost-shared, deep drilling of most favorable } \\
\text { exploration targets. }\end{array}$} \\
\hline \multicolumn{10}{|l|}{$\begin{array}{l}\text { Complete integration of geochemical processes into reservoir } \\
\text { simulators. }\end{array}$} \\
\hline \multicolumn{10}{|l|}{$\begin{array}{l}\text { Complete joint testing, with industry, of reservoir simulator for } \\
\text { use as a production management tool. }\end{array}$} \\
\hline $\begin{array}{l}\text { Demonstrate full-field reservoir strategy for location and flow } \\
\text { rate control of injection wells. }\end{array}$ & & & & & & & & & $\bullet$ \\
\hline Apply new exploration methodology at candidate sites. & & & & & & & & & $\bullet$ \\
\hline Present unified concept for geothermal exploration technology. & & & & & & & & & $\bullet$ \\
\hline
\end{tabular}




\begin{tabular}{|c|c|c|c|c|c|c|c|c|c|}
\hline & \multicolumn{4}{|c|}{ FY 1992} & \multirow[b]{2}{*}{ FY 1993} & \multirow[b]{2}{*}{ FY 1994} & \multirow[b]{2}{*}{ FY 1995} & \multirow[b]{2}{*}{ FY 1996} & \multirow[b]{2}{*}{ FY 1997} \\
\hline MILESTONE & 1 & 2 & 3 & 4 & & & & & \\
\hline Hard Rock Penetration & & & & & & & & & \\
\hline Conduct field test of velocity-level flow transducer. & $\bullet$ & & & & & & & & \\
\hline Initiate collection of cost data for conventional exploration. & - & & & & & & & & \\
\hline $\begin{array}{l}\text { Initiate development of downhole injector and SEA-MIST } \\
\text { hardware. }\end{array}$ & & $\bullet$ & & & & & & & \\
\hline $\begin{array}{l}\text { Complete identification of needs for high-temperature slimhole } \\
\text { drilling fluids. }\end{array}$ & & $\bullet$ & & & & & & & \\
\hline Initiate field test of drillable straddle packer. & & & $\bullet$ & & & & & & \\
\hline Initiate field test of high-temperature lost circulation materials. & & & $\bullet$ & & & & & & \\
\hline Initiate development of borehole instruments with industry. & & & $\bullet$ & & & & & & \\
\hline $\begin{array}{l}\text { Conduct field test of high-temperature positive displacement } \\
\text { motor. }\end{array}$ & & & - & & & & ' & & \\
\hline Complete development of porous packer. & & & & $\bullet$ & & & & & \\
\hline $\begin{array}{l}\text { Initiate field test to compare production in large and small } \\
\text { wellbores. }\end{array}$ & & & & - & & & & & \\
\hline Build PDC coring bits and initiate testing. & & & & - & & & & & \\
\hline $\begin{array}{l}\text { Initiate design of drilling hardware for cost effective } \\
\text { emplacement of vertical heat exchangers for geothermal-based } \\
\text { heat pumps. }\end{array}$ & & & & $\bullet$ & & & & & \\
\hline $\begin{array}{l}\text { Initiate field test of modular electronic tools in geothermal } \\
\text { wells. }\end{array}$ & & & & $\bullet$ & & & & & \\
\hline $\begin{array}{l}\text { Complete development of downhole injector, small-scale } \\
\text { laboratory studies of cementitious muds, and wellbore hydraulic } \\
\text { models. }\end{array}$ & & & & & $\bullet$ & & & & \\
\hline
\end{tabular}




\begin{tabular}{|c|c|c|c|c|c|c|c|c|c|}
\hline \multirow[b]{2}{*}{ MLESTONE } & \multicolumn{4}{|c|}{ FY 1992} & \multirow[b]{2}{*}{ FY 1993} & \multirow[b]{2}{*}{ FY 1994} & \multirow[b]{2}{*}{ FY 1995} & \multirow[b]{2}{*}{ FY 1996} & \multirow[b]{2}{*}{ FY 1997} \\
\hline & 1 & 2 & 3 & 4 & & & & & \\
\hline \multicolumn{10}{|l|}{ Hard Rock Penetration (Continued) } \\
\hline \multicolumn{10}{|l|}{$\begin{array}{l}\text { Conduct geothermal heat pump National Utilities Awareness } \\
\text { Campaign }\end{array}$} \\
\hline \multicolumn{10}{|l|}{$\begin{array}{l}\text { Identify needs and begin development of surface technology for } \\
\text { coring rigs. }\end{array}$} \\
\hline \multicolumn{10}{|l|}{ Begin development of high-temperature drilling fluids. } \\
\hline \multicolumn{10}{|l|}{ Initiate development of high-temperature core barrels. } \\
\hline \multicolumn{10}{|l|}{$\begin{array}{l}\text { Initiate fabrication of drilling hardware for heat pump } \\
\text { installation. }\end{array}$} \\
\hline \multicolumn{10}{|l|}{$\begin{array}{l}\text { Begin design of advanced coring system for geothermal } \\
\text { exploration. }\end{array}$} \\
\hline \multicolumn{10}{|l|}{$\begin{array}{l}\text { Initiate development of fiber optic cables for high-temperature } \\
\text { logging above } 300^{\circ} \mathrm{C} \text {. }\end{array}$} \\
\hline \multicolumn{10}{|l|}{ Complete large-scale laboratory tests of cementitious muds. } \\
\hline \multicolumn{10}{|l|}{$\begin{array}{l}\text { Initiate development of expert systems for lost circulation } \\
\text { control. }\end{array}$} \\
\hline \multicolumn{10}{|l|}{ Complete development of SEA-MIST hardware. } \\
\hline \multicolumn{10}{|l|}{$\begin{array}{l}\text { Initiato development of high-temperature slimhole drilling fluids } \\
\text { and lost circulation materials. }\end{array}$} \\
\hline \multicolumn{10}{|l|}{$\begin{array}{l}\text { Initiate field test of cementitious muds, expert systems for lost } \\
\text { circulation control, and SEA-MIST hardware. }\end{array}$} \\
\hline \multicolumn{10}{|l|}{$\begin{array}{l}\text { Complete development of emplacement system for geothermal } \\
\text { heat pump ground loops. }\end{array}$} \\
\hline $\begin{array}{l}\text { Demonstrate one-day installation of residential geothermal heat } \\
\text { pumps in cooperation with industry. }\end{array}$ & & & & & & $\bullet$ & & & \\
\hline
\end{tabular}




\begin{tabular}{|c|c|c|c|c|c|c|c|c|c|}
\hline \multirow[b]{2}{*}{ MILESTONE } & \multicolumn{4}{|c|}{ FY 1992} & \multirow[b]{2}{*}{ FY 1993} & \multirow[b]{2}{*}{ FY 1994} & \multirow[b]{2}{*}{ FY 1995} & \multirow[b]{2}{*}{ FY 1996} & \multirow[b]{2}{*}{ FY 1997} \\
\hline & $\mathbf{1}$ & 2 & $\mathbf{3}$ & 4 & & & & & \\
\hline \multicolumn{10}{|l|}{ Hard Rock Penetration (Continued) } \\
\hline Drill cost-shared exploratory corehole with industry. & & & & & & & - & & \\
\hline Initiate advanced drilling concepts for goothermal applications. & & & & & & & & - & \\
\hline $\begin{array}{l}\text { Transfer cementitious mud lost circulation technology to } \\
\text { industry. }\end{array}$ & & & & & & & & $\bullet$ & \\
\hline Develop measurement-whilo-drilling tools for geothermal wells. & & & & & & & & - & \\
\hline $\begin{array}{l}\text { Transfer expert system tochnology for lost circulation to } \\
\text { industry. }\end{array}$ & & & & & & & & & - \\
\hline Transfer core drilling technology to industry. & & & & & & & & & - \\
\hline Field test fiber optic system. & & & & & & & & & - \\
\hline Field test measurement-while-drilling tools. & & & & & & & & & $\bullet$ \\
\hline \multicolumn{10}{|l|}{ Conversion Technology - Heat Cycle Reseanch } \\
\hline $\begin{array}{l}\text { Complete investigation of condensation behavior of isobutane in } \\
\text { simulated supersaturated turbine expansions. }\end{array}$ & & $\bullet$ & & & & & & & \\
\hline $\begin{array}{l}\text { Complete supercritical cycle investigations and report on } \\
\text { imposod binary cycle designs producing } 20 \% \text { performance } \\
\text { improvements. }\end{array}$ & & & - & & & & & & \\
\hline $\begin{array}{l}\text { Complete advanced heat rejection system scoping studies and } \\
\text { select one for field investigations. }\end{array}$ & & & & $\bullet$ & & & & & \\
\hline $\begin{array}{l}\text { Complete investigations of condensation behavior of } \\
\text { supersaturated turbine expansions. }\end{array}$ & & & & & - & & & & \\
\hline $\begin{array}{l}\text { Complete INEL feasibility study of incorporating advanced } \\
\text { plant concepts into a standardized modular binary plant design. }\end{array}$ & & & & & - & & & & \\
\hline $\begin{array}{l}\text { Solicit industrial interest in cost-shared development of modular } \\
\text { binary plant which incorporates improved binary cycle design. }\end{array}$ & & & & & & - & & & \\
\hline
\end{tabular}




\begin{tabular}{|c|c|c|c|c|c|c|c|c|c|}
\hline & \multicolumn{4}{|c|}{ FY 1992} & \multirow[b]{2}{*}{ FY 1993} & \multirow[b]{2}{*}{ FY 1994} & \multirow[b]{2}{*}{ FY 1995} & \multirow[b]{2}{*}{ FY 1996} & \multirow[b]{2}{*}{ FY 1997} \\
\hline MILESTONE & 1 & 2 & 3 & 4 & & & & & \\
\hline \multicolumn{10}{|l|}{ Conrersion Technology - Heat Cycle Research (Continued) } \\
\hline \multicolumn{10}{|l|}{ Complete investigations of advanced heat rejection systems. } \\
\hline \multicolumn{10}{|l|}{ Close out operation of HCRF. } \\
\hline Field test prototype modular energy conversion system. & & & & & & & & $\bullet$ & \\
\hline \multicolumn{10}{|l|}{ Conversion Technology - Materials Development } \\
\hline \multicolumn{10}{|l|}{ Complete downhole testing of $\mathrm{CO}_{2}$-resistant cement samples. } \\
\hline \multicolumn{10}{|l|}{ Complete cementing activities in demonstration well. } \\
\hline \multicolumn{10}{|l|}{ Complete development of chemical coupling system. } \\
\hline \multicolumn{10}{|l|}{ Complete technology transfer of drill pipe protectors. } \\
\hline \multicolumn{10}{|l|}{$\begin{array}{l}\text { Technical feasibility of cementitious muds established in } \\
\text { laboratory tests. }\end{array}$} \\
\hline \multicolumn{10}{|l|}{ Complete development of elastomeric liners for well casing. } \\
\hline \multicolumn{10}{|l|}{$\begin{array}{l}\text { Initiate technology transfer of high-temperature cements to } \\
\text { industry. }\end{array}$} \\
\hline \multicolumn{10}{|l|}{ Complete pilot-scale flow tests of cementitious muds. } \\
\hline \multicolumn{10}{|l|}{ Complete field demonstration of elastomeric liners. } \\
\hline \multicolumn{10}{|l|}{$\begin{array}{l}\text { Complete tochnical feasibility study for placement of ceramic } \\
\text { liners. }\end{array}$} \\
\hline \multicolumn{10}{|l|}{$\begin{array}{l}\text { Complete well demonstration of cementitious muds and transfer } \\
\text { technology to industry. }\end{array}$} \\
\hline \multicolumn{10}{|l|}{ Complete downhole testing of prototype ceramic-lined sections. } \\
\hline Conduct field demonstration of ceramic-lined casing. & & & & & & & $\bullet$ & & \\
\hline
\end{tabular}




\begin{tabular}{|c|c|c|c|c|c|c|c|c|c|}
\hline \multirow[b]{2}{*}{ MILESTONE } & \multicolumn{4}{|c|}{ FY 1992} & \multirow[b]{2}{*}{ FY 1993} & \multirow[b]{2}{*}{ FY 1994} & \multirow[b]{2}{*}{ FY 1995} & \multirow[b]{2}{*}{ FY 1996} & \multirow[b]{2}{*}{ FY 1997} \\
\hline & 1 & 2 & 3 & 4 & & & & & \\
\hline \multicolumn{10}{|l|}{ Conversion Technology - Brine Chemistry } \\
\hline Initiate materials study for bioreactor design. & • & & & & & & & & \\
\hline Initiate lesting and application of brine model to field problems. & - & & & & & & & & \\
\hline Complete model of $\mathrm{pH}$ in high-temperature brines. & & - & & & & & & & \\
\hline Issue report on brine kinetics. & & & $\bullet$ & & & & & & \\
\hline $\begin{array}{l}\text { Initiate study of mineral recovery from geothermal residual } \\
\text { waste. }\end{array}$ & & & $\bullet$ & & & & & & \\
\hline Complete preliminary model of $\mathrm{H}_{2} \mathrm{~S}-\mathrm{H}_{2} \mathrm{O}$ solubility in brines. & & & & - & & & & & \\
\hline Initiate construction of new generation bioreactor. & & & & & $\bullet$ & & & & \\
\hline $\begin{array}{l}\text { Complete study of mineral recovery from geothermal residual } \\
\text { waste. }\end{array}$ & & & & & - & & & & \\
\hline $\begin{array}{l}\text { Complete testing and application of brine model to field } \\
\text { pmoblems. }\end{array}$ & & & & & - & & & & \\
\hline Complete update of brine model user's manual. & & & & & $\bullet$ & & & & \\
\hline $\begin{array}{l}\text { Initiate preliminary model of aluminum speciation as a function } \\
\text { of } \mathrm{pH} \text {. }\end{array}$ & & & & & - & & & & \\
\hline Initiate literature search for metal sulfide data. & & & & & - & & & & \\
\hline Complete construction of new generation bioreactor. & & & & & & $\bullet$ & & & \\
\hline Initiate process development studies. & & & & & & $\bullet$ & & & \\
\hline Complete process development studies. & & & & & & - & & & \\
\hline Initiate third economic study. & & & & & & $\bullet$ & & & \\
\hline $\begin{array}{l}\text { Complete preliminary model of bisulfate species in high- } \\
\text { temperature program. }\end{array}$ & & & & & & - & & & \\
\hline
\end{tabular}




\begin{tabular}{|c|c|c|c|c|c|c|c|c|c|}
\hline \multirow[b]{2}{*}{ MILESTONE } & \multicolumn{4}{|c|}{ FY 1992} & \multirow[b]{2}{*}{ FY 1993} & \multirow[b]{2}{*}{ FY 1994} & \multirow[b]{2}{*}{ FY 1995} & \multirow[b]{2}{*}{ FY 1996} & \multirow[b]{2}{*}{ FY 1997} \\
\hline & 1 & 2 & 3 & 4 & & & & & \\
\hline \multicolumn{10}{|l|}{ Conversion Technology - Brine Chemistry (Continued) } \\
\hline Initiate comparative brine kinetic studies and modifications. & & & & & & & - & & \\
\hline $\begin{array}{l}\text { Complete identification of best candidates for further bioreactor } \\
\text { scale-up with industry. }\end{array}$ & & & & & & & & - & \\
\hline Build commercial-scale bioreactor with industry. & & & & & & & & & - \\
\hline \multicolumn{10}{|l|}{ GEOPRESSURED RESEARCH } \\
\hline Initiate facility design at Hulin well site. & - & & & & & & & & \\
\hline Initiate pressure buildup test of Pleasant Bayou reservoir. & - & & & & & & & & \\
\hline $\begin{array}{l}\text { Complete construction of production facilities at Hulin well } \\
\text { site. }\end{array}$ & & & & - & & & & & \\
\hline Complete pressure buildup test of the Pleasant Bayou reservoir. & & & & - & & & & & \\
\hline $\begin{array}{l}\text { Complete data analysis and model development of the Pleasant } \\
\text { Bayou reservoir. }\end{array}$ & & & & & - & & & & \\
\hline $\begin{array}{l}\text { Complete scientific lests at Pleasant Bayou and plug and } \\
\text { abandon or transfer to industry. }\end{array}$ & & & & & - & & & & \\
\hline Conduct flow test of Hulin reservoir. & & & & & - & & & & \\
\hline Plug and abandon Hulin well or transfer well to industry. & & & & & - & & & & \\
\hline Complete all reseanch reports except environmental monitoring. & & & & & & - & & & \\
\hline Complete final report on environmental monitoring. & & & & & & & - & & \\
\hline \multicolumn{10}{|l|}{ ADVANCED SYSTEMS - HOT DRY ROCK } \\
\hline Begin Long-Term Flow Test (LTFT). & & & - & & & & & & \\
\hline Commence in-depth analysis of LTFT data. & & & & & - & & & & \\
\hline Complete study of Phase II reservoir fluid mineralization. & & -- & & & - & & & & \\
\hline
\end{tabular}




\begin{tabular}{|c|c|c|c|c|c|c|c|c|c|}
\hline \multirow[b]{2}{*}{ MILESTONE } & \multicolumn{4}{|c|}{ FY 1992} & \multirow[b]{2}{*}{ FY 1993} & \multirow[b]{2}{*}{ FY 1994} & \multirow[b]{2}{*}{ FY 1995} & \multirow[b]{2}{*}{ FY 1996} & \multirow[b]{2}{*}{ FX 1997} \\
\hline & 1 & 2 & 3 & 4 & & & & & \\
\hline \multicolumn{10}{|l|}{ ADVANCED SYSTEMS - HOT DRY ROCK (Continued) } \\
\hline Demonstrate reliability of temperature-sensitive trac & & & & & $\bullet$ & & & & \\
\hline \multicolumn{10}{|c|}{$\begin{array}{l}\text { Begin evaluation of enhanced power production modes (multi- } \\
\text { well, cyclic). }\end{array}$} \\
\hline \multicolumn{10}{|l|}{ Complete LTFT. } \\
\hline \multicolumn{10}{|l|}{ Issue preliminary report on LTFT results. } \\
\hline \multicolumn{10}{|l|}{ Decommission Fenton Hill site. } \\
\hline \multicolumn{10}{|l|}{ Document economics of enhanced production modes. } \\
\hline \multicolumn{10}{|c|}{$\begin{array}{l}\text { Initiate investigation of zone isolation and impedance reduction } \\
\text { technology. }\end{array}$} \\
\hline \multicolumn{10}{|l|}{ Issue final reports on LTFT. } \\
\hline Complete impedance reduction technology study. & & & & & & & & - & \\
\hline Initiate first joint hot dry rock project with industry & & & & & & & & - & \\
\hline
\end{tabular}

